\title{
Pengaruh Pertumbuhan Penjualan, Current Ratio, Debt to Equity Ratio terhadap Kinerja Keuangan PT.Sirma Pratama Nusa Periode 2014-2017
}

\author{
Levita Judini Tasmil \\ Universitas Prima Indonesia \\ levitajudini@yahoo.com

\section{Novintan Malau} \\ Universitas Prima Indonesia \\ Novintanmalau@gmail.com
}

\section{Marwah Nasution}

Universitas Prima Indonesia

Marwahnasution94@gmail.com

\begin{abstract}
Abstrak Penelitian ini dimaksudkan untuk menguji pengaruh Pertumbuhan Penjualan, Current Ratio dan Debt to Equity Ratio terhadap kinerja keuangan. Penelitian ini dilakukan di PT. Sirma Pratama Nusa dalam kurun waktu 2014-2017 dengan total populasi 48 bulan. Teknik pengambilan sampel yang digunakan dalam penelitian ini adalah pengambilan sampel jenuh dan diperoleh 48 bulan sampel. Hasil Dari penelitian ini adalah Current Ratio dan Debt to Equity Ratio mempengaruhi kinerja keuangan secara parsial dan Pertumbuhan Penjualan, Current Ratio dan Debt to Equity Ratio mempengaruhi kinerja keuangan secara simultan. Dengan diperkuat koefisien determinasi (R2) sebesar 0,988 yang menunjukkan bahwa 98,8\% dari kinerja keuangan dapat dijelaskan oleh variabel pertumbuhan penjualan Current Ratio dan Debt to Equity ratio. Sedangkan sisanya $1,2 \%$ dipengaruhi oleh variabel lain diluar model yang diteliti.
\end{abstract}

Kata Kunci Pertumbuhan Penjualan, Current Ratio, Debt to Equity Ratio, Kinerja Keuangan

\section{PENDAHULUAN}

Kelapa sawit merupakan komoditi perkebunan yang banyak dikembangkan di Indonesia. Luas tanaman kelapa sawit telah meningkat dengan pesat. Sejak tahun 1967 luas kebun sawit telah meningkat 35 kali lipat menjadi sekitar 5,6 juta ha tahun 2005 dan sekitar 9,5 juta ha pada tahun 2012. Peta penyebaran perkebunan kelapa sawit di Indonesia mencakup 22 Provinsi.

PT.SIRMA PRATAMA NUSA merupakan salah satu perusahaan yang bergerak di bidang perkebunan kelapa sawit yang berada di Rundeng, Subulussalam, Aceh Selatan. PT.SIRMA PRATAMA NUSA memiliki luas perkebunan 176 hektar dengan bidang 
usaha penjualan tandan buah segar (TBS) ke pabrik kelapa sawit (PKS). PT.SIRMA PRATAMA NUSA memiliki karakteristik usaha yang baik dan spesifik serta mampu bersaing dengan perkebunan sawit yang lain. Hal ini dapat terlihat dari komposisi pengelolaan kebun dan kebun inti yang bagus sehingga dalam melakukan pengelolaan dibutuhkan kepiawaian dalam hal pengelolaan dan tanggung jawab.

Pertumbuhan Penjualan mencerminkan pencapaian perusahaan di masa lalu, dimana pertumbuhan penjualan digunakan untuk memprediksikan pencapaian perusahaan di masa depan. Pertumbuhan penjualan juga dapat menunjukkan daya saing perusahaan dalam pasar. Apabila pertumbuhan penjualan semakin meningkat, maka akan menambah laba yang besar bagi perusahaan. Namun apabila suatu perusahaan tidak menggunakan secara efisien total aset yang ada diperusahaan maka akan berdampak pada menurunnya tingkat pertumbuhan penjualan pada suatu perusahaan, yang akan mengakibatkan juga menurunnya tingkat kinerja keuangan didalam perusahaan. (Valentina:2017)

Tingginya tingkat likuiditas suatu perusahaan akan menggambarkan bahwa perusahaan tersebut mampu memenuhi jangka pendeknya. Current Ratio menunjukkan sejauh mana aktiva lancar suatu perusahaan menutupi kewajiban lancar. Semakin besar perbandingan aktiva lancar maka akan semakin tinggi pula kemampuan perusahaan untuk menutupi kewajiban jangka pendek (Harahap, 2016:301). Semakin tinggi nilai Current ratio menunjukkan bahwa ketersediaan aktiva lancar untuk memenuhi nilai dari kewajiban lancar juga tinggi (Supardi:2016).

Tingginya utang suatu perusahaan menggambarkan bahwa kinerja keuangan suatu perusahaan berjalan dengan baik. Hal ini dapat dilihat dengan semakin banyaknya utang suatu perusahaan membuktikan bahwa banyak transaksi keuangan yang terjadi. Hal ini juga mampu mengurangi jumlah tagihan pajak yang harus dibayar suatu perusahaan sehingga labanya meningkat. Namun tingkat utang juga dapat memberikan dampak yang tidak baik bagi perusahaan, jika tingkat utang tidak diperhatikan maka akan menyebabkan turunnya laba karena menimbulkan beban bunga yang bersifat tetap. (Mahardika:2016).

\section{LANDASAN TEORI}

\section{Pertumbuhan Penjualan}

Menurut Kasmir (2017:114), Pertumbuhan penjualan merupakan rasio yang menggambarkan kemampuan perusahaan dan mempertahankan posisi ekonominya ditengah pertumbuhan ekonomi dan sektor usahanya. Pertumbuhan penjualan mencerminkan keberhasilan investasi periode masa lalu dan dapat dijadikan sebagai prediksi pertumbuhan masa yang akan datang.

$$
\text { Pertumbuhan Penjualan }=\frac{\text { Penjualan tahun înĩ }- \text { Penjualan tahun lalu }}{\text { Penjualan tahun lalu }}
$$

\section{Current Ratio}

Menurut Hery (2017:287) Rasio lancar merupakan rasio yang digunakan untuk mengukur kemampuan perusahaan dalam memenuhi kewajiban jangka pendeknya yang segera jatuh tempo dengan menggunakan total aset lancar yang tersedia. 


$$
\text { Current Ratio }=\frac{\text { Current } \text { Asset }}{\text { Current Liabilities }}
$$

\section{Debt to Equity Ratio}

Menurut Jusuf J (2014:60) Debt to Equity Ratio yaitu perbandingan antara total kewajiban (total utang) dengan total modal sendiri (equity). Rasio ini menunjukkan jaminan yang diberikan modal sendiri atas utang yang diterima oleh perusahaan Jusuf. J (2014:60)

$$
\text { Debt to Equity Ratio }=\frac{\text { Total Debts }}{\text { Total Equity }}
$$

\section{Kinerja Keuangan}

Menurut Syamsyuddin (2013:37) Kinerja keuangan perusahaan pada dasarnya merupakan perhitungan ratio-ratio untuk menilai keadaan keuangan perusahaan di masa lalu, saat ini, dan kemungkinannya di masa depan.

$$
\text { Return on Asset }=\frac{\text { Laba bersilt }}{\text { Total } \text { Asset }}
$$

\section{Pertumbuhan Penjualan terhadap Kinerja Keuangan}

Menurut Brigham (2012:396), menyatakan bahwa tingkat pertumbuhan yang negative menunjukkan perusahaan yang sedang menurun. Hal ini akan menyebabkan kerugian modal. Sehingga harga saham perusahaan yang sedang menurun relatif rendah.

\section{Current Ratio terhadap Kinerja Keuangan}

Menurut Sawir (2009:8), Current ratio yang rendah biasanya dianggap menunjukkan terjadinya masalah dalam likuiditas. Sebaliknya suatu perusahaan yang current ratio-nya terlalu tinggi juga kurang bagus, karena menunjukkan banyaknya dana menganggur yang pada akhirnya dapat mengurangi kemampuan laba perusahaan.

\section{Debt to Equity Ratio terhadap Kinerja Keuangan}

Menurut Sartono (2010:121), semakin tinggi rasio ini maka semakin besar rasio yang dihadapi, dan investor akan meminta tingkat keuntungan yang semakin tinggi. Rasio yang tinggi juga menunjukkan proporsi modal sendiri yang rendah untuk membiayai aktiva. 


\section{Kerangka Konseptual}

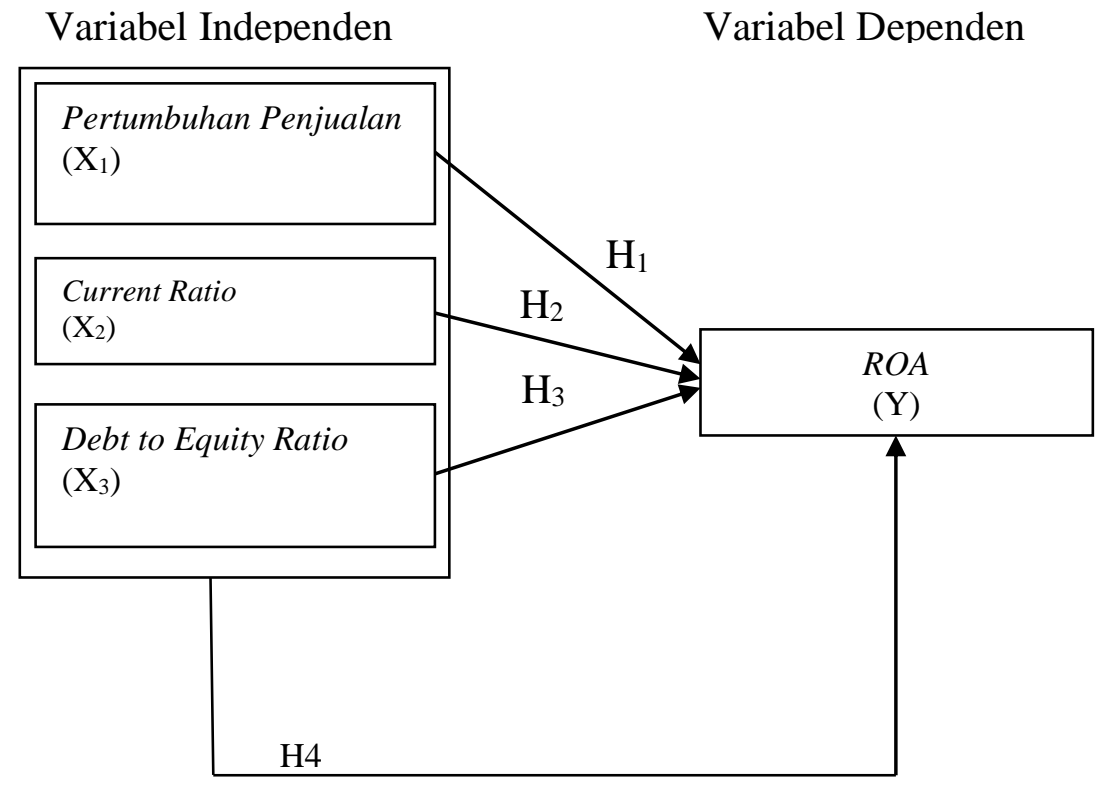

\section{METODOLOGI PENELITIAN}

Jenis penelitian yang digunakan dalam penelitian ini adalah penelitian deskriptif kuantitatif. Penelitian ini dilakukan dengan mengambil data pada perusahaan PT.Sirma Pratama Nusa pada tahun 2014-2017. Populasi dalam penelitian ini yaitu data keuangan PT. Sirma Pratama Nusa dengan sampel sebanyak 48. Penarikan sampel dilakukan dengan teknik sampel jenuh, yaitu kesuluruhan laporan keuangan pada PT Sirma Pratama Nusa tahun 2014-2017.

Identifikasi dan definisi operasional variabel dalam penelitian ini adalah variabel independen atau variabel bebas yang artinya variabel ini yang mempunyai pengaruh terhadap variabel dependen. Pada penelitian ini variabel independen yaitu Pertumbuhan Penjualan, Current Ratio dan Debt to Equity Ratio. Variabel dependen atau variabel terikat adalah variabel yang dipengaruhi atau yang menjadi sebab akibat. Variabel dependen dalam penelitian ini adalah Kinerja Keuangan.

\section{HASIL DAN PEMBAHASAAN}

\section{Uji Normalitas}

Uji normalitas bertujuan untuk menguji apakah dalam model regresi, variabel penggangu atau residual memiliki distribusi normal. Kalau uji normalitas ini dilanggar maka uji statistik menjadi tidak valid untuk jumlah sampel yang kecil. 


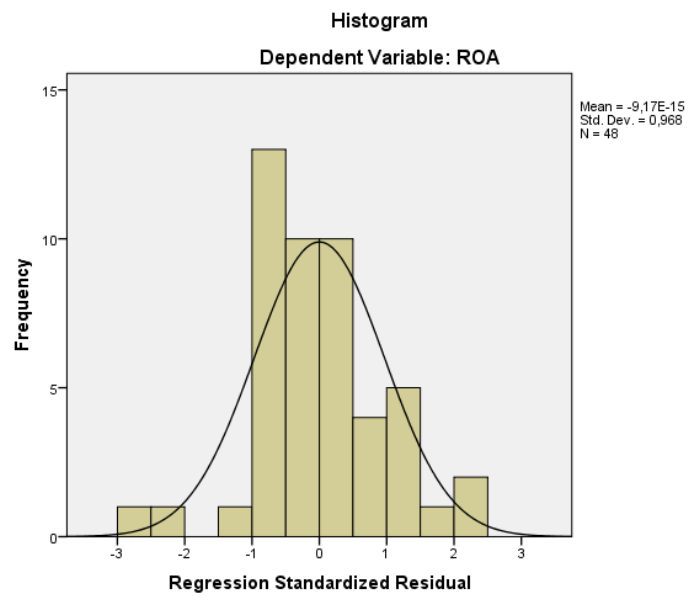

Sumber : Hasil Dari Pengolahan Data SPSS

One-Sample Kolmogorov-Smirnov Test

\begin{tabular}{|ll|r|}
\hline & & \multicolumn{2}{|c|}{ Unstandardized } \\
& & 48 \\
$\mathrm{~N}$ & Mean & .0000000 \\
Pormal & Std. & .09093440 \\
& Deviation & .095 \\
Most & Absolute & .084 \\
Extreme & Positive & -.095 \\
Differences & Negative & .095 \\
Test Statistic & & $.200^{\mathrm{c}}$ \\
Asymp. Sig. (2-tailed) & \\
\hline
\end{tabular}
a. Test distribution is Normal.
b. Calculated from data.
c. Lilliefors Significance Correction.

Hasil dari uji Kolmogorov Smirnov pada tabel diatas menunjukkan nilai kolmogorov smirnov adalah 0,200. Dengan demikian sig $>0,05$ maka data ini dapat dikatakan berdistribusi normal.

\section{Uji Multikolinearitas}

Uji multikolinearitas bertujuan untuk menguji apakah pada model regresi ditemukan adanya korelasi antar variabel independen. Pada model regresi yang baik seharusnya tidak terjadi korelasi antar variabel independen. Pengujian multikolinearitas 
dilakukan dengan melihat VIF antar variabel independen. Uji multikolonieritas dapat dilakukan dengan melihat nilai tolerance dan nilai VIF dengan kriteria nilai tolerance $>$ 0,10 dan nilai $\mathrm{VIF} \leq 10$.

\section{Coefficients $^{\mathrm{a}}$}

\begin{tabular}{|rl|l|l|}
\hline \multirow{2}{*}{ Model } & & \multicolumn{2}{|l|}{$\begin{array}{l}\text { Collinearity } \\
\text { Statistics }\end{array}$} \\
\cline { 3 - 4 } & & Tolerance & VIF \\
\hline $1 \quad$ (Constant) & & \\
& Pertumbuhanpenjualan & .985 & 1.015 \\
& CR & .118 & 8.487 \\
& DER & .117 & 8.529 \\
\hline
\end{tabular}

a. Dependent Variable: ROA

Sumber: Hasil dari Pengolahan data SPSS

Nilai tolerance variabel Pertumbuhan Penjualan, Current Ratio dan Debt to Equity Ratio berada $>0,10$. Sedangkan nilai VIF Pertumbuhan Penjualan, Current Ratio, dan Debt to Equity Ratio berada <10. Dengan demikian hasil uji multikolinearitas dapat disimpulkan tidak terjadi kolerasi antara independen.

\section{Uji Autokolerasi}

Uji autokorelasi bertujuan menguji apakah dalam model regresi linear ada korelasi antara kesalahan pengganggu periode $\mathrm{t}$ dengan kesalahan pengganggu periode $\mathrm{t}-1$ (sebelumnya). Uji autokolerasi dalam penelitian ini dilakukan dengan menggunakan uji Run Test.

Runs Test

\begin{tabular}{|l|r|}
\hline & \multicolumn{2}{|l|}{$\begin{array}{l}\text { Rnstandardized } \\
\text { Residual }\end{array}$} \\
\hline Test Value $^{\mathrm{a}}$ & -.01223 \\
Cases < Test Value & 24 \\
Cases >= Test Value & 24 \\
Total Cases & 48 \\
Number of Runs & 20 \\
Z & -1.313 \\
Asymp. Sig. (2-tailed) & .189 \\
\hline
\end{tabular}

a. Median

Sumber : Hasil dari Pengolahan dat SPSS 
Nilai sig dari uji Run Test diatas adalah sebesar 0,189 berada diatas 0,05 maka dapat disimpulkan dalam uji autokorelasi dengan menggunakan uji run test tidak terdapat gejala atau masalah auto korelasi.

\section{Uji Heteroskedastisitas}

Pendeteksian ada tidaknya heteroskedastisitas dapat dilakukan dengan menggunakan metode Glejser Test, yaitu dengan cara meregresikan nilai absolute residual terhadap variabel independen.

\section{Coefficients $^{\mathrm{a}}$}

\begin{tabular}{|c|c|c|c|c|c|}
\hline \multirow[b]{2}{*}{ Model } & \multicolumn{2}{|c|}{$\begin{array}{c}\text { Unstandardized } \\
\text { Coefficients }\end{array}$} & \multirow{2}{*}{$\begin{array}{l}\begin{array}{r}\text { Standardized } \\
\text { Coefficients }\end{array} \\
\text { Beta }\end{array}$} & \multirow[t]{2}{*}{$\mathrm{T}$} & \multirow[t]{2}{*}{ Sig. } \\
\hline & $\mathrm{B}$ & Std. Error & & & \\
\hline 1 (Constant) & .123 & .129 & & .956 & .344 \\
\hline $\begin{array}{l}\text { Pertumbuhan } \\
\text { penjualan }\end{array}$ & -.021 & .015 & -.198 & -1.387 & .172 \\
\hline $\mathrm{CR}$ & .000 & .001 & .094 & .227 & .821 \\
\hline DER & -.004 & .010 & -.175 & -.424 & .674 \\
\hline
\end{tabular}

Hasil uji glejser pada tabel diatas menunjukkan nilai sig dari Pertumbuhan Penjualan, Current Ratio, Debt to Equity Ratio lebih besar dari 0,05 maka dari hasil uji diatas tidak terjadi masalah heteroskedastisitas.

\section{Analisis Linier Berganda}

\section{Uji statistik t}

Coefficients $^{\text {a }}$

\begin{tabular}{|c|c|c|c|c|c|}
\hline \multirow[b]{2}{*}{ Model } & \multicolumn{2}{|c|}{$\begin{array}{l}\text { Unstandardized } \\
\text { Coefficients } \\
\end{array}$} & \multirow{2}{*}{$\begin{array}{l}\text { Standardized } \\
\text { Coefficients } \\
\text { Beta } \\
\end{array}$} & \multirow[b]{2}{*}{$\mathrm{T}$} & \multirow[b]{2}{*}{ Sig. } \\
\hline & $\mathrm{B}$ & Std. Error & & & \\
\hline $1 \quad$ (Constant) & 1.752 & .215 & & 8.159 & .000 \\
\hline $\mathrm{X} 1$ & .015 & .025 & .004 & .585 & .562 \\
\hline $\mathrm{X} 2$ & .118 & .002 & .850 & 48.796 & .000 \\
\hline $\mathrm{X} 3$ & -.145 & .016 & -.158 & -9.036 & .000 \\
\hline
\end{tabular}

a. Dependent Variable: Y

Berdasarkan tabel diatas diperoleh hasil analisis regresi linier berganda, yaitu :

$\mathrm{Y}=1,752+0,015 \mathrm{X}_{1}+0,118 \mathrm{X}_{2}-0,145 \mathrm{X}_{3}$

Dari tabel tersebut dapat kita lihat bahwa, Current Ratio berpengaruh positif dan signifikan terhadap Kinerja Keuangan. Debt to Equity Ratio berpengaruh negatif dan signifikan terhadap Kinerja Keuangan. Hal ini dibuktikan dengan tingkat signifikansi yang diperoleh $<0,05$. Sedangkan untuk Pertumbuhan Penjualan tidak memiliki pengaruh terhadap Kinerja Keuangan pada PT Sirma Pratama Nusa tahun 2014-2017. Hal ini dibuktikan dengan tingkat signifikansi pada Pertumbuhan penjualan $<0,05$. 


\section{Uji Statistik F}

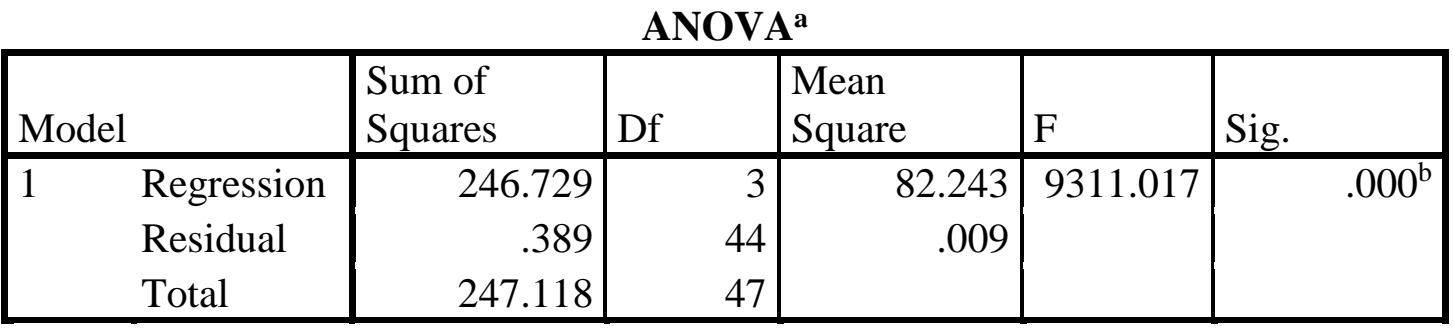

a. Dependent Variable: Y

b. Predictors: (Constant), X3, X1, X2

Berdasarkan hasil uji $\mathrm{F}$ diatas, nilai $\mathrm{F}$ hitung sebesar 9311,017 > Ftabel 2,82 dengan nilai sig 0,000 $<0,05$ menunjukkan bahwa variabel Pertumbuhan Penjualan, Current Ratio dan Debt to Equity Ratio berpengaruh secara simultan terhadap Kinerja Keuangan.

\section{Uji Koefisien Determinasi}

Model Summary ${ }^{b}$

\begin{tabular}{|c|c|c|c|c|c|c|c|c|c|}
\hline \multirow[b]{2}{*}{$\begin{array}{l}\text { Mo } \\
\text { del }\end{array}$} & \multirow[b]{2}{*}{$\mathrm{R}$} & \multirow[b]{2}{*}{$\begin{array}{l}\mathrm{R} \\
\text { Square }\end{array}$} & \multirow[b]{2}{*}{$\begin{array}{l}\text { Adjusted } \\
\text { R Square }\end{array}$} & \multirow{2}{*}{$\begin{array}{l}\text { Std. Error } \\
\text { of the } \\
\text { Estimate }\end{array}$} & \multicolumn{5}{|c|}{ Change Statistics } \\
\hline & & & & & $\begin{array}{l}\text { R Square } \\
\text { Change }\end{array}$ & $\begin{array}{l}\mathrm{F} \\
\text { Change }\end{array}$ & df1 & $\mathrm{df} 2$ & $\begin{array}{l}\text { Sig. F } \\
\text { Change }\end{array}$ \\
\hline 1 & $.999^{\mathrm{a}}$ & .998 & .998 & .09398332 & .998 & $\begin{array}{r}9311.01 \\
7\end{array}$ & 3 & 44 & .000 \\
\hline
\end{tabular}

a. Predictors: (Constant), X3, X1, X2

b. Dependent Variable: Y

Berdasarkan hasil diatas, diperoleh nilai adjust square sebesar 0,998 yang berarti pengaruh Pertumbuhan Penjualan, Current Ratio dan Debt to Equity Ratio terhadap Kinerja Keuangan sebesar 99,8\% sedangkan 1,2\% dipengaruhi oleh variabel lain.

\section{KESIMPULAN}

Berdasarkan hasil penelitian yang telah dilakukan dapat disimpulkan bahwa secara parsial Pertumbuhan Penjualan tidak berpengaruh positif dan signifikan terhadap Kinerja Keuangan perusahaan dengan nilai signifikansi variabel bebas yang >0,05. Secara parsial Current Ratio berpengaruh positif dan signifikan terhadap Kinerja keuangan dengan nilai signifikansi $<0,05$. Secara parsial Debt to Equity Ratio berpengaruh negatif dan signifikan terhadap Kinerja Keuangan perusahaan dengan nilai signifikansi <0,05. Hal ini sejalan dengan pendapat Munawarah (2017) yang menyatakan Leverage menunjukkan rasio tingkat penggunaan utang untuk menghasilkan dana atau ekuitas. Debt to equity ratio (DER) sebagai indikator penggunaan utang menunjukkan smakin tinggi DER akan dianggap kurang aman bagi kreditor dan mengarah kepada kebangkrutan karena menurunnya kemampuan perusahaan menghasilkan laba. Secara simultan Pertumbuhan Penjualan, Current Ratio 
dan Debt to Equity Ratio berpengaruh positif dan signifikan terhadap Kinerja Keuangan perusahaan dengan nilai signifikansi $<0,05$.

\section{DAFTAR PUSTAKA}

Ayu, Putri Mahardika.et.al. 2016. Pengaruh Current Ratio dan Debt to Equity Ratio Terhadap Return on Assets.Jurnal Widyakala.Vol 3 Maret.

Brigham, Eugene F. \& Joel F. Houston. 2012. Dasar-dasar Manajemen Keuangan. Ed. 11, Jakarta: Salemba Empat.

Ghozali, Imam. 2013. Aplikasi Analisis Multivariate dengan Program IBM SPSS 23. Ed. 8, Semarang: Badan Penerbit Universitas Diponegoro.

Hery. 2017. Teori Akuntansi : Pendekatan Konsep dan Analisis. Jakarta: PT Grasindo, Anggota IKAPI.

Jusuf. 2014. Analisis Kredit Untuk Credit (Account) Officer. Cetakan Kedua Belas. Jakarta: PT Gramedia Pustaka Utama.

Kasmir. 2017. Analisis Laporan Keuangan. Cetakan Kesepuluh. Jakarta: Rajawali Pers.

Munawarah, M. 2017. Pengaruh Earning Power, Firm Size, Dan Leverage Terhadap Earning Management Pada Perusahaan Sub Sektor Food And Beverage Yang Terdaftar Di Bursa Efek Tahun 2011-2015. Jurnal Mutiara Akuntansi.Vol.2 (1).

Sartono, Agus. 2010. Manajemen Keuangan Teori dan Aplikasi. Ed. 4, Yogyakarta: BPFE-Yogyakarta.

Sawir, Agnes. 2009. Analisis Kinerja Keuangan dan Perencanaan Keuangan Perusahaan. Cetakan Kelima. Jakarta: PT SUN.

Sugiyono. 2017. Metode Penelitian Bisnis. Ed.13, Bandung: Alfabeta.

Supardi, Herman.et.al. 2016. Pengaruh Current Ratio, Debt to Asset ratio, Total Asset Turnover dan Inflasi Terhadap Return on Asset. Jurnal Ilmiah Akuntansi Fakultas Ekonomi Vol.2 (2).

Syamsuddin, Lukman. 2013. Manajemen Keuangan Perusahaan: Konsep Aplikasi dalam Perencanaan, Pengawasan, dan pengambilan Keputusan (Edisi Baru).Cetakan Keduabelas. Jakarta: Rajawali Pers.

Valentina, Henni \& Ruzikna. 2017. Pengaruh Struktur Modal, Risiko Bisnis Dan Pertumbuhan Penjualan Terhadap Kinerja Keuangan Pada Perusahaan Real Estate And Property Yang Terdaftar Di Bursa Efek Indonesia Tahun 20102014. Jom Fisip Vol. 4 No.2 - Oktober 